\title{
PENGARUH KOMPRES PANAS TERHADAP PENURUNAN NYERI HAID PADA MAHASISWA AKPER KESDAM I/BB MEDAN
}

\author{
Effect of Heat Compress to Decrease in Menstrual \\ Pain Nursing Academy Students Kesdam I / BB Medan
}

\author{
Erita Gustina \\ Dosen Tetap Yayasan Akper kesdam I/BB Medan \\ Email : eritaangga@yahoo.com
}

\begin{abstract}
Abstrak
Nyeri haid merupakan nyeri yang dialami pada saat haid yang diikuti dengan perubahan mental maupun fisik yang terjadi pada hari pertama atau kedua masa haidnya. Pada kebanyakan wanita yaitu $80 \%$ wanita muda dibawah 25 tahun mengalami nyeri haid, namun hal tersebut hanya merupakan gejala primer yang biasa tanpa implikasi yang serius dan mudah diatasi (Declan,1997). Dan sering bertambahnya usia pada wanita mengakibatkan nyeri cenderung untuk menurun dan akhirnya hilang sama sekali setelah melahirkan (Smeltzer,2001).

Desaian penelitian yang digunakan dalam penelitian ini adalah quasi eksperimen yaitu eksperimen yang mengontrol situasi penelitian menggunakan rancangan tertentu dan atau penunjukan subyek secara niracak untuk mendapatkan salah satu dari berbagai tingkat faktor penelitian. Populasi dalam penelitian ini adalah mahasiswa Akper Kesdam I/BB Medan Tk II dan III yang berumur 20 tahun dengan siklus yang teratur dan mengalami nyeri haid. Penelitian ini menggunakan sampel 74 mahasiswa dengan pembagian 37 kelompok untuk intervensi dan 37 untuk kelompok pembanding yang tidak dilakukan tindakan kompres panas. Waktu penelitian dilakukan selama 2 bulan mulai dari bulan September sampai dengan Okober 2010 sesuai dengan siklus haid masing-masing responden.

Hasil penelitian diperoleh rata-rata skala nyeri pada kelompok yang mendapat intervensi kompres panas adalah 0,92 dengan standar deviasi 0,547, sedangkan untuk kelompok pembanding yang tidak mendapat pelakuan kompres panas, rata-ratanya adalah 2,24 dengan standar deviasi 0,495. Hasil uji statistic t-test independen didapatkan nilai p value 0,000 , berarti pada alpa $5 \%$ terlihat ada perbedaan yang sihnifikan rata-rata kelompok intervensi dengan kelompok pembanding setelah mendapat intervensi kompres panas.

Dapat disimpulkan ada perbedaan bermakna antara rata-rata intensitas nyeri haid pada kelompok intervensi dan kelompok pembanding dengan $\mathrm{p}$ value responden yang didapat setelah dilakukan penelitian kebanyakan beragama Islam dan bersuku Batak. Setelah dilakukan kompres panas responden mengalami perubahan fisik rasa sakit berkurang, haid lancar dan dapat beraktifitas seperti biasa. Penelitian ini diharapkan dapat digunakan sebagai data dasar bagi penelitian selanjutnya dan dapat dijadikan sebagai sumber pengetahuan dan strategi bagi perawat dalam memberikan asuhan keperawatan yang lebih komprehensif pada pasien yang berkaitan dengan penatalaksanaan nyeri haid.
\end{abstract}

Kata kunci : Kompres panas terhadap penurunan nyeri haid

\begin{abstract}
Menstrual pain is pain experienced during menstruation, followed by mental and physical changes that occur in the first or second day of the menstrual period. In most women, namely $80 \%$ of young women below 25 years of experience menstrual pain, but it was only a symptom of the usual primary without serious implications and easily overcome (Declan, 1997). And often increasing age in women resulting in pain tend to decline and eventually disappear altogether after childbirth (Smeltzer, 2001).Desaian research used in this research is quasi experiment is an experiment that controls the situation of studies using specific design and or non-appointment of the subjects randomized to receive one of the various levels of factors research. The population in this study were students Akper Kesdam I / BB Terrain Level II and III that are 20 years old with a regular cycle and experiencing menstrual pain. This study used a sample of 74 students with a division for the intervention group 37 and 37 for a comparison group that did not do the action hot compress. The research was carried out for 2 months from September to Okober 2010 in accordance with the menstrual cycle each respondent.The results obtained by the average scale of pain in the intervention group receiving a hot compress is 0.92 with a standard deviation of 0.547 , while the comparison group who did not receive the commission of a hot compress, the average is 2.24 with a standard deviation of 0,495 . The results of statistical tests obtained independent t-test $\mathrm{p}$ value of 0.000 , meaning at alpha $5 \%$ seen no difference in the average sihnifikan intervention group with a comparison group after the intervention gets hot compress.

It can be concluded there were significant differences between the average intensity of menstrual pain in the intervention group and the comparison group respondents with $\mathrm{p}$ value obtained after the study mostly
\end{abstract}


Muslim and ethnic Batak. After a hot compress respondents experienced physical changes reduced pain, menstrual smoothly and can work as usual. This research is expected to be used as a baseline for future research and can be used as a source of knowledge and strategies for nurses in providing more comprehensive nursing care to patients associated with menstrual pain management.

Keywords: hot compress to decrease menstrual pain

\section{Pendahuluan}

Pada wanita yang normal mulai dari usia remaja hingga dewasa, setiap bulannya secara periodik akan mengalami peristiwa reproduksi yang disebut menstrusi atau haid, yaitu pengeluaran darah dari alat kandungan (dinding rahim wanita) yang terjadi secara teratur melalui vagina. Keluarnya darah melalui vagina karena tidak adanya telur matang yang dibuahi oleh sprema sehingga terjadi peluruhan lapisan dalam rahim yang banyak mengandung pembuluh darah (Mochtar,1998).

Wanita yang menderita nyeri sering menyembunyikan rasa sakitnya tanpa mengetahui apa yang harus dilakukan untuk mengatasi nyeri haid yang dialaminya. Mereka menganggap bahwa nyeri haid itu adalah rasa sakit yang wajar. Tetapi apabila nyeri yang dirasakan semakin lama semakin hebat dan dapat menggangu aktivitas sehari-hari, dan bahkan ada yang tidak sanggup melakukan aktivitas sama sekali dan hanya mampu berbaring dan menahan rasa sakitnya barulah mereka mencari pengobatan untuk segera mengatasi nyeri, salah satunya dengan mengkonsumsi obat-obatan analgetik seperti panadol, aspirin, atau beberapa obat lain yang dapat menghilangkan atau minimal membantu mengurangi nyeri haid yang menggangu kenyamanan penderita (Kingston,2000).

Mengacu pada teori dari Asosiasi Nyeri Internasional, pemahaman tentang nyeri lebih menitikberatkan bahwa nyeri adalah kejadian fisik, yang tentu saja untuk penatalaksanaan nyeri menitikberatkan pada manipulasi fisik atau menghilangkan penyebab fisik. Sedangkan dari definisi menurut Mahon, pemahaman tentang nyeri tidak hanya menitikberatkan bahwa nyeri adalah kejadian fisik semata, namun nyeri dipahami sebagai suatu hal yang holistic, memahami pengalaman nyeri sebagaimana nyeri

itu berlangsung. Penatalaksanaan nyeri lebih dari sekedar pemberian analgesik namun penting juga untuk melakukan manipulasi atau tindakan psikologis untuk mengatasi nyeri.

Nyeri adalah sensasi ketidaknyamanan yang dimanifestasikan sebagai penderitaan yang diakibatkan oleh persepsi jiwa yang nyata, ancaman, dan fantasi luka (Kozzier dan Erb, 1983 dalam Tamsuri,2006).

Skala Sederhana Intensitas Nyeri

(1) Deskripsi sederhana terdiri dari :

- Tidak nyeri-nyeri berat

- Nyeri sedang-nyeri sangat berat
(2) Grafic Verbal Ranting Scale

(3) Visual Analogue Scale

(4) Numerical Ranting Scale

(Sumber : Panel petunjuk manajemen nyeri akut, 1992 dikutip oleh Marie, 2002 )

Nyeri haid merupakan rasa nyeri atau sakit pada saat haid yang dapat dirasakan di perut bagian bawah atau pinggang dan berupa sakit mulasmulas, ngilu atau rasa seperti ditusuk-tusuk yang berlangsung pada saat menjelang haid, atau beberapa hari setelah haid datang (Mortowijono \& Kuswanto, 1989).

Hampir semua wanita mengalami rasa tidak enak perut bawah sebelum dan selama haid, sehingga memaksa penderita untuk istirahat dan meninggalkan pekerjaan atau aktivitasnya seharihari, untuk beberapa jam atau beberapa hari (Simajuntak, 1997).

Desain penelitian yang digunakan dalam penelitian ini adalah quasi eksperimen yaitu eksperimen yang dalam mengontrol situasi penelitian menggunakan rancangan tertentu dan atau penunjukan subyek secara nir-acak untuk mendapatkan salah satu dari berbagai tingkat factor penelitian.

Hasil Penelitian

1. Karakteristik Responden

Setelah dilakukan penelitian di Akper Kesdam I/BB Medan karakteristik responden dapat dilihat dari table dibawah ini.

Tabel 5. 1. Distribusi karakteristik kelompok intervensi responden mahasiswa Akper Kesdam I/BB Medan berdasarkan Agama $(\mathbf{N}=37)$

\begin{tabular}{lcc}
\hline Agama & $\mathrm{F}$ (orang) & persentase $(\%)$ \\
\hline Islam & 16 & 43,2 \\
Kristen & 14 & 37,8 \\
Katolik & 7 & 18,9 \\
\hline Total & 37 & 100 \\
\hline
\end{tabular}

Dari tabel 5.1 diatas terlihat bahwa kelompok intervensi 43,2\% (n=16) responden beragama Islam, sedangkan agama Kristen 37,8\% $(\mathrm{n}=14)$ dan Katolik 18,9\% (7).

Tabel 5. 2. Distribusi karakteristik kelompok pembanding responden mahasiswa Akper Kesdam I/BB Medan berdasarkan Agama (N=37)

\begin{tabular}{lcc}
\hline Agama & $\mathrm{f}$ (orang) & persentase $(\%)$ \\
\hline Islam & 19 & 51,4 \\
Kristen & 13 & 35,1 \\
Katolik & 5 & 13,5 \\
\hline
\end{tabular}


Dari tabel 5.2 diatas terlihat bahwa kelompok pembanding $51,4 \% \quad(n=19)$ responden mayoritas beragama Islam, sedangkan agama Kristen 35,1\% ( $\mathrm{n}=13)$ dan Katolik 13,5\% (5).

Tabel 5. 3. Distribusi karakteristik kelompok intervensi responden mahasiswa Akper Kesdam I/BB Medan berdasarkan Suku $\mathbf{N}=37$ )

\begin{tabular}{lcc}
\hline Suku & $\mathrm{f}$ (orang) & persentase $(\%)$ \\
\hline Batak & 20 & 54,1 \\
Jawa & 13 & 35,1 \\
Minang & 1 & 2,7 \\
Melayu & 3 & 8,1 \\
\hline Total & 37 & 100 \\
\hline
\end{tabular}

Dari tabel 5.3 di atas terlihat bahwa kelompok intervensi 54,1\% $\quad(n=20)$ mayoritas responden bersuku Batak, sedangkan $35,1 \%$ $(\mathrm{n}=13)$ bersuku Jawa, 2,7\% $(\mathrm{n}=1)$ bersuku Minang dan Melayu 8,1\% (3).

Tabel 5. 4. Distribusi karakteristik kelompok pembanding responden mahasiswa Akper Kesdam I/BB Medan berdasarkan Suku (N=37)

\begin{tabular}{lcc}
\hline Suku & $\mathrm{f}$ (orang) & persentase $(\%)$ \\
\hline Batak & 23 & 62,2 \\
& $n$ &
\end{tabular}

Jurnal Riset Hesti Medan, Vol. 1, No. 1 Juni 2016

\begin{tabular}{lll}
\hline Total & 37 & 100 \\
\hline
\end{tabular}

Dari tabel 5.3 di atas terlihat bahwa kelompok pembanding $62,2 \% \quad(n=23)$ mayoritas responden bersuku Batak, sedangkan 24,3\% ( $n=9)$ bersuku Jawa, 5,4\% ( $\mathrm{n}=2)$ bersuku Minang dan Melayu $8,1 \%$ (3).

\section{Pengaruh kompres panas terhadap penurunan nyeri haid pada mahasiswa Akper Kesdam I/BB Medan}

Dari hasil penelitian diperoleh data pengaruh kompres panas terhadap penurunan skala nyeri haid, terlihat pada tabel dibawah ini

Tabel 5.5. Distribusi rata-rata skala nyeri haid menurut pengukuran pertama dan kedua pada mahasiswa Akper Kesdam yang mendapat intervensi kompres panas dan tidak mendapat kompres panas

\begin{tabular}{lrrrrr}
\hline Intervensi & Mean SD & SE & p value & N \\
\hline - Kompres & 0,92 & 0,547 & 0,90 & 0,000 & 37 \\
- Tdk.kompres2,24 & 0,495 & 0,81 & & 37 \\
\hline
\end{tabular}

Rata-rata skala nyeri haid pada kelompok yang mendapat intervensi kompres panas adalah 0,92 dengan standar deviasi 0,547. Sedangkan untuk kelompok pembanding yang tidak mendapat pelakuan kompres panas, rata-rata adalah 2,24 dengan standar deviasi 0,495.

Hasil uji statistic t-test independen didapatkan nilai $p$ value 0,000 , berarti pada alpha $5 \%$ terlihat ada perbedaan yang signifikan ratarata kelompok intervensi dengan kelompok pembanding setelah mendapat intervensi kompres panas.

\section{Pembahasan \\ 1. Agama}

Berdasarkan hasil penelitian kebanyakan responden beragama Islam, hal ini disebabkan karena jumlah mahasiswi di Akper kesdam dari 200 mahasiswi 112 beragama Islam.

Kepercayaan, agama mempengaruhi persepsi seseorang terhadap nyeri. Dalam agama tertentu,kesabaran adalah hal yang paling berharga dimata Tuhan. Kadang-kadang nyeri dianggap sebagai peringatan atas kesalahan yang telah dibuat sehingga orang tersebut merasa pasrah dalam menghadapi nyeri (Taylor, 1997).

2. Suku

Sedangkan hasil penelitian karakteristik responden yang berhubungan dengan suku, sebagian besar responden bersuku Batak. Dari 200 mahasiswi Akper 108 orang bersuku batak. Keyakinan dan nilai-nilai budaya mempengaruhi cara individu mengatasi nyeri. Individu mempelajari apa yang diharapkan dan apa vang diterima oleh kebudayaan mereka. Hal : 67 iputi bagaimana bereaksi terhadap nyeri (C ${ }^{67}$ dan Flaskerud, 1991 dalam Potter \& Perry, 2005).

3. Pengaruh kompres panas terhadap penurunan nyeri haid

Kompres panas adalah salah satu teknik dari stimulasi kulit yang dilakukan untuk menghilangkan nyeri dan merupakan langkahlangkah sederhana dalam upaya menurunkan persepsi nyeri. Kompres panas dapat dilakukan untuk mengatasi nyeri haid, karena penggunaan panas dapat meredakan iskemia dengan menurunkan kontrasi otot-otot rahim sehingga dapat memperlancar aliran darah mestruasi (Bobak, dkk, 2004).

Kompres panas selain memberikan efek mengatasi atau menghilangkan sensasi nyeri, teknik ini juga memberikan reaksi fisiologi antara lain (1) memperbesar pembuluh darah (vasodilatasi) sehingga dapat meningkatkan aliran darah kebagian tubuh yang mengalami nyeri, meningkatkan pengiriman nutrisi dan pembuangan zat sisa, mengurangi kongesti vena didalam jaringan yang mengalami nyeri atau cedera (2) menurunkan viskositas darah sehingga meningkatkan pengiriman leukosit dan antibiotik ke daerah yang mengalami cedera atau luka (3) menurunkan ketegangan otot sehingga otot-otot mengalami nyeri akibat spamsme atau kekakuan dapat kembali 
relaksasi (4) meningkatkan metabolism jaringan (5) meningkatkan permeabilitas kapiler sehingga meningkatkan pergerakan zat sisa dan nutrisi (Potter \& Perry, 2005).

Hasil penelitian diperoleh data pada kelompok intervensi yang melakukan kompres panas mengalami perubahan objektif antara lain nyeri yang dirasakan berkurang dari sebelumnya dari skala nyeri tujuh menjadi tiga, ini terjadi karena dengan melakukan kompres panas pada lokasi nyeri responden penurunan ketegangan otot dan dapat kembali berelaksasi. Selain itu juga dalam observasi peneliti responden mengalami pembesaran pembuluh darah sehingga aliran darah meningkat ke bagian tubuh yang mengalami nyeri sehingga darah haid menjadi lancar. Sedangkan pada kelompok yang tidak dilakukan intervensi responden tidak mengalami perubahan.

Dan dari hasil uji statistik t-test independen didapatkan rata-rata skala nyeri haid pada kelompok yang mendapat intervensi kompres panas adalah 0,92 dan standar deviasi 0,547 dengan nilai $p$ value 0,000 .

\section{Simpulan dan Saran Simpulan}

Responden yang mengalami nyeri haid kebanyakan beragama Islam dan bersuku batak. Rata-rata intensitas nyeri haid pada kelompok intervensi adalah 0,92 dan kelompok pembanding adalah 2,24 . Ada perbedaan bermakna antara ratarata intensitas nyeri haid pada kelompok intervensi dan kelompok pembanding dengan $p$ value 0,000 .

\section{Saran}

Dalam pratek keperawatan diharapkan penelitian ini dapat dijadikan sebagai sumber pengetahuan dan strategi bagi perawat dalam memberikan asuhan keperawatan yang lebih komprehensif pada pasien yang berkaitan dengan penatalaksanaan nyeri haid.

Penelitian Keperawatan diharapkan dapat digunakan sebagai data dasar bagi penelitian selanjutnya dalam ruang lingkup yang sama dengan penambahan variabel seperti aktivitas fisik, stres, penyakit sistemik dan kelelahan dalam pengaruh penurunan nyeri haid.

Pendidikan Keperawatan diharapkan dapat menjadi data tambahan dalam mengembangkan pendidikan keperawatan, terutama dibidang keperawatan maternitas.

\section{Daftar Pustaka}

Arifin, S, (2002). Nyeri Haid. Online dari http://www.ipin4u.esmartstudent.com/haid.h $\underline{\text { tm }}$, di askes tanggal 6 Pebruari 2009

Arikunto, S. (2006). Prosedur Penelitian: Suatu Pendekatan Praktik (Edisi Revisi IV). Jakarta: PT Asdi Mahasatya
Azwar, S. (2003). Reliabilitas dan Validasi. Yogyakarta: Pustaka Pelajar Offset

Bobak, dkk. (2004). Buku Ajar Keperawatan Maternitas. Ed. 4. Jakarta: EGC

Berger, K. J. (1992). Fundamental of Nursing: Collaborating for Optimal Health. Neurosensory Integration. Connecticurt: Appleton \& Lange. Hal. 1351-1352, 1384, 1396-1400.

Brink, P. J. dan Wood, M. J. (1998). Langkah Dasar Dalam Perencanaan Riset Keperawatan: dari Pertanyaan sampai Proposal. Jakarta: EGC

Dempsey, P. A. \& Dempsey, A. D. (2002). Riset Keperawatan : Buku Ajar dan Latihan. Edisi 4. Jakarta: EGC

Danim, S. (2003). Riset Keperawatan: Sejarah dan Metodologi. Jakarta: EGC

Declan, T.W. (1997). Vitamin E untuk Mengurangi Nyeri Haid. Online dari http://id.shvoong.com/medicine-andhealth/1647436-vitamin-untuk-menguranginyeri-haid/. Diakses tanggal 6 Pebruari 2009

Edjun, JJ. (2001). Kiat sukses Pasangan Memperoleh Keturunan. Jakarta: Puspa Suara

Hacker \& Moore. (2001). Esensial Obstetri dan Ginekologi. Philadelphia : Pensylvania

Hegner, Barbara R, Cald Well, Esther. (2003). Asisten Keperawatan.Suatu Pendekatan.Proses Keperawatan. Jakarta : EGC

Hairani.W (2008). Efektif Kompres Panas Terhadap Penurunan Nyeri haid.PSIK FK USU : Medan. Skripsi. Tidak untuk dipublikasikan

Kingston, B. (2000). Mengatasi Nyeri Haid. Jakarta: Arcan

Llewellyn, D.(2005). Setiap Wanita. Jakarta : Delapratasa Publishing

Llewellyn,D. (2001). Dasar-dasar Obstetri dan Ginekologi. Ed. 6. Jakarta : Hipokrates

Manuaba, (1998). Ilmu Kebidanan, Penyakit Kandungan dan Keluarga Berencana. Jakarta : EGC

Martowijono \& Kuswanto, O. (1989). Problem Wanita Menghadapi Menopouse. Jakarta

Marie, (2002). Panel Petunjuk Manajemen Nyeri Akut

Mochtar,R. (1998). Sinopsis Obstetri : Obstetri Fisiologis, Obstetri Patologi. Ed 2. Jakarta :EGC

Murti,B.(1997). Prinsip dan Metode Riset Epidemiologi, cetakan Pertama Gajah Mada University Press, Yogyakarta.

Nursalam.(2003). Konsep \& Penerapan Metodologi Penelitian Ilmu Keperawatan. Jakarta : Salemba Medika 
Notoadmojo, S. (2005). Metodologi Penelitian Kesehatan. Cetakan ketiga. Jakarta : PT. Rineka Cipta

Okparasta, A. (2008). Dismenorea. Online dari http://fkunsri.wordpress.com/2008/02/06/dis menorea.part-1 diaskes pada tanggal 6 Pebruari 2009

Potter, P. A. \& Perry, A.G. (2005). Fundamental Keperawatan : Konsep, Proses dan Praktek. Jakarta : EGC

Price, S. (1997). Aroma Terapi bagi Profesi Kesehatan. Jakarta : EGC

Ragawaluya,B.(1997). Ketegangan Premenstrual. Bandung : Pioner Jaya

Rayburn,W. F. (2001). Obstetri dan Ginekologi. Jakarta : Widya Medika

Ratur, B. (1992). Nyeri Haid. Seminar FK USU 18 Juli 1992. Medan

Priharjo, R. (1996). Perawatan Nyeri : Pemenuhan Aktivitas Istirahat Pasien. Jakarta : EGC

Sitompul, N. (2005). Efektivitas Teknik Relasasi Napas Dalam dan Pengaturan Posisi yang Nyaman terhadap Penurunan Nyeri Haid pada Wanita Usia Produktif. PSIK FK USU : Medan. Skripsi. Tidak untuk dipublikasikan.
Simanjuntak, P. (1997). Gangguan Haid dan Siklusnya Dalam Prawirohardjo, S. (ed) : Ilmu Kandungan. Cetakan 2. Jakarta : PT Gramedia

Smeltzer, S. C. (2001). Buku ajar Keperawatan Medikal Bedah Brunner \& Suddath/editor, Suzanne C. Smeltzer, Brenda G. Bare : alih bahasa, Agung Waluyo, (et.al): editor edisi bahasa Indonesia, Monica Ester, Ellen Panggabean. ( $8^{\text {th }}$ ed $)$. Jakarta : EGC

Tamsuri, A. (2006). Konsep \& Penatalaksanaan Nyeri. Jakarta : EGC

Taylor, C. (1997). Fundamentals of Nursing : The Art Science of Nursing Carel Caro Taylor, Carol Lilis, Priscilla LeMone. ( $\left.3^{\text {rd }} \mathrm{Ed}\right)$. Philadelphia : Lippincott-Raven Publishers

Vedder, T. (2007). Vitamin E untuk Mengurangi Nyeri Haid. Online dari http://id. shvoong.com/medicine-andhealth/1647436-vitamin-untuk-menguranginyeri-haid/.diaskes diakses tanggal 6 Pebruari 2009

Declan, T. W. (1997). Kapita Selekta Penyakit dan Terapi. Jakarta : EGC

Winknjosastro, H, dkk. (2005). Ilmu Kandungan. Ed.4. Jakarta: Yayasan Bina Pustaka Sarwono Prawirohardjo 